Research Article

Corresponding Author: Matt Beech, Department of Politics, University of Hull, Cottingham Road, Hull, HU6 7RX, UK

Email: m.beech@hull.ac.uk

\title{
Brexit and the Decentred State
}

\section{Matt Beech \\ University of Hull, UK}

\begin{abstract}
The aim of this article is to examine Brexit through the lens of decentred theory as articulated by Bevir (2013) in A Theory of Governance. Decentered theory regards the British state as neither a monolith (as per modernist social science) nor a myth (as per post-modern theory) but rather as a repository of norms, customs, practices and thought acquired by elite actors, professionals and policy-networks. The central thesis of the article is that the idea of the decentered state, as an explanation of state governance, can be seen in the phenomenon of Brexit. The article uses literatures on governance and contemporary history to examine the relevance of the concept of the decentered state. Then it considers the case study of British politics in the 1970s as a precursor to the decentering effects of Brexit on state governance. The article then moves to consider three dimensions of the phenomenon of Brexit which can be understood as decentering practices in and of themselves: the referendum vote; the negotiations; and competing 'imaginings' of the United Kingdom in a post-EU membership environment. The article's findings represent a fresh and novel means by which scholars can utilise the idea of the decentered state as an intellectual tool to explain the phenomenon of Brexit.
\end{abstract}

\section{Keywords}

Brexit, Decentred State, Governance, United Kingdom 


\section{Introduction}

The decision for the United Kingdom to withdraw from the European Union (EU) is the most important political and constitutional decision taken in living memory. The decision was taken in a nation-wide referendum held on $23^{\text {rd }}$ June 2016. The result was a victory for the two 'Leave' campaigns and was predicated on a turnout of $72 \%$ of registered electors, with $52 \%$ voting to 'Leave' and $48 \%$ voting to 'Remain'. The campaign was long. It ran from $15^{\text {th }}$ April to $23^{\text {rd }}$ June. It was often bitter and ill-tempered. The airwaves, the press, the internet in general, and social media in particular, were replete with arguments, data, counterpoints, misinformation and criticism. With the triggering of Article 50 of the Lisbon Treaty on $29^{\text {th }}$ March 2017, the minority Conservative government led by Theresa May, activated the legal mechanism for the United Kingdom's exit from the EU. In the days that followed, the arguments continued often generating more heat than light. Arguments abound pertaining to the shape and form of Brexit; the implementation or 'transition' period; the post-membership relationships; and, most controversially, whether the British electorate wish to revisit their decision.

This article's central thesis is that the idea of the decentered state ${ }^{1}$, as an explanation of state governance, can be used to interpret the phenomenon of Brexit. For Bevir (2013), the merit of decentered theory is that it:

...emphasizes the diversity of governing practices and the importance of historical explanations of these practices. Governance is seen as a set of diverse practices that people are constantly creating and recreating through their concrete activity. (Bevir, 2013:1)

Bevir's use of decentred theory interprets how state actors respond to significant change. It gives credence to agency, ideas and beliefs and emphasises the evolution and adaptation of 
This is the author's final version of a manuscript accepted for publication as Beech, M. (2020). Brexit and the decentred state. Public Policy and Administration. https://doi.org/10.1177/0952076720905008

traditions, practices and behaviours. This theory of a 'diversity of governing practices' is a feature of the British state. There was a 'diversity of governing practices' and contested narratives prior to the United Kingdom joining the European Community on $1^{\text {st }}$ January 1973 through to ratifying the Maastricht Treaty in July 1993 and on to the June 2016 referendum, to today and beyond, when the United Kingdom eventually exits the EU.

It is because Brexit is fundamentally a struggle about wresting sovereignty from the EU back to the Houses of Parliament and, by so doing, altering the governing practices of the last four decades that makes it necessarily a decentering event. What is argued below is that regardless of whether one thinks, or desires from a normative perspective, that Brexit will lead to the United Kingdom being meaningfully independent of a supra-national federal politics, the sheer act of 'Brexiting' is a decentering event in and of itself. Evans and Menon (2017) are correct when they suggest that:

Brexit will also provide the British state with arguably its most severe peace-time challenge. The Cabinet Secretary reckons it has few, if any, parallels in its complexity. (Evans and Menon, 2017: 108)

The article will begin by discussing the relevance of the concept of the decentered state as an explanatory theory of state governance in the United Kingdom. Then it will consider the case study of British politics in the 1970s as a precursor to the decentering effects of Brexit on state governance which was an example of an extended period marked by shock, schism, rupture and characterised by disputes. Next the article analyses three aspects of Brexit and how each one contributes to the decentering of state governance: the referendum vote, the negotiation and the competing ideational visions of the United Kingdom after EU membership. 


\section{The Decentered State and British Politics}

The concept of the decentered state is a post-foundationalist theory of the state. It is relevant in seeking to explain and understand the workings of the British state as it acknowledges that the British state is neither a monolith (as per modernist social science) nor a myth (as per post-modern theory). The concept of the decentered state contains a good measure of explanatory accuracy which surpasses classical institutionalist, Marxist and post-modern accounts of the state.

The British state is objectively real though not merely in a physical sense e.g. the buildings of institutions such as the Houses of Parliament or HM Treasury or in the outputs of such institutions, namely published Acts of Parliament and documents of fiscal policy. The British state, according to decentered theory, is real in an ideational sense. This is because it is composed of ideas, beliefs, historical traditions and governing practices (Bevir, 2013). In this ideational sense, the British state can be understood as a repository of norms, customs and thought acquired by elite actors, professionals and policy networks. Rhodes and Marsh (1992), as proponents of policy networks as a meso-level concept of interest group intermediation, seek to move beyond the dichotomy of pluralist and corporatist models of interest representation (Rhodes and Marsh, 1992: 2-4) and they suggest that policy networks, in and of themselves, are not adequate to explain policy change:

...the meso-level concept of 'policy networks' needs to be clearly located in a number of macro-theories of the state, and the articulation between the levels needs to be specified. This latter exercise is an important reminder that policy networks are but a component, albeit an important one, of any explanation of policy making and policy change in Britain. (Marsh and Rhodes, 1992: 268) 
The concept of the decentered state is a viable macro-theory of the state. The British state is large, multi-layered, multi-institutional and comprises governing practices and traditions of thought which a plurality of stakeholders - i.e. Backbench Members of Parliament, Ministers of the Crown, civil servants, public and private sector professionals - author and re-author. These governing practices, much like traditions of thought, are not harmonious but contested and neither do they correspond to a rational plan. Moreover, the historical context of the state activity matters. Referring to the evolving activity and responsibility of democratic states Gamble (2016) argues that:

In the twentieth century, the state gradually assumed major roles in stabilising and regulating market economies to prevent slumps and promote growth and prosperity; in providing social protection and social investment through welfare, education and health programmes; and in investing to promote technological innovation, provide better infrastructure and foster faster growth. States have as a result become multipurpose, multi-agency and multi-layered, with highly complex systems of governance and co-ordination. (Gamble, 2016:7)

The British state can be efficient in discharging its duties and providing goods and services but because it is dynamic and multifarious and ultimately authored by intentional stakeholders - acting in groups and organisations with contrasting norms and goals - it is susceptible to shock, schism, rupture and is characterised by disputes. As it is authored by humans it is marked by failure. Having considered the relevance of the concept of the decentred state as an explanatory theory of the British state, the article moves to consider the case study of British politics in the 1970s. This provides an example of an extended period marked by shock, schism, rupture and characterised by disputes which serves as a precursor to the decentering effects of Brexit on state governance. 


\section{Decentering of the British State: The 1970s as Case Study}

When surveying the modern British state, one is aware that 'modern' refers to the post-war era. Of all the periods in the aftermath of the Second World War, it is contended here that a good example of the British state experiencing shock, schism, rupture and marked by dilemmas and disputes between individuals, groups, their beliefs and ideational traditions is the politics of the 1970s. In the post-war era the 1970s was the most difficult decade to govern the United Kingdom. The OPEC oil crisis; the industrial relations question; stagflation; racial tension; clashing moral values; the Troubles in Northern Ireland; arguments over membership of the Common Market; football hooliganism; the emergence of radical feminism; and punk were markers of a nation exhibiting the birth pangs of social and economic transformation. These ideas, attitudes and events were underpinned by a sense that Britain's ancien regime was neither desirable nor effective in empowering individual liberty. This spirit was, in itself, a rupture in the British or more precisely in the English mind. ${ }^{2}$ The ties that had for so long bonded - endogenously and exogenously - the four nations of the Union and its collective institutions including the Protestant churches, the Crown, holy matrimony, Parliament and political parties, manufacturing and trade unions, that provided a thick sense of community and identity, began to matter much less. Economic individualism, moral liberation and post-modernity affected the settled institutions of the United Kingdom with radical formulas of what it and its people ought to become.

The British state was subject to decentering from within through ruptures in social ethics and cultural practice and from without in the form of economic crises. Related to stagflation and ongoing strike action was the decentring effect that the decline of Keynesianism had on the governance of economic management. Keynesianism had been the preferred economic doctrine since 1945 but by the mid-1970s, with the emergence of the IMF Crisis, it became apparent that the instruments of demand management that Labour and Conservative 
governments had utilised in the age of Butskellism and beyond were leading to higher doses of inflation which, in turn, prompted concomitant demands for wage increase. The industrial relations backdrop was symbolised by the divided nature of the Wilson Cabinet which led to the inability to muster sufficient support to legislate on its 1969 White Paper In Place of Strife; the failure of the Heath Government to enforce the trade union reforms laid out in the Industrial Relations Act 1971; and the willingness of Wilson's minority Labour Government to replace the Industrial Relations Act 1971 with the Trade Union and Labour Relations Act 1974. The two great parties of British parliamentary democracy were ill-equipped to navigate the challenge to state governance and economic management that the twin pressures of stagflation and militant strike action caused in the 1970s. Politicians, civil servants, trade unionists and business leaders failed to embrace change at a level of ideas, norms and practices so to facilitate a more effective approach to industrial relations.

By 1976, the British state was once gain faced with a major decentering crisis: the IMF Crisis (Coates, 1975; Hickson, 2005). Chancellor Denis Healey made an application, the second within a year, to the International Monetary Fund (IMF) for a $\$ 3.9$ billion loan. The Government needed the loan due the parlous state of its public finances. Large budget deficits had been run up in an era of high unemployment and high inflation. Tax receipts were low and as was to be expected the welfare bill was rising. Add to this the pressure that was brought to bear on Sterling in March 1976 after significant sales of the currency by the Bank of England and further currency speculation on Sterling in July of the same year. But, more than anything else, the economic and political morass that was the industrial relations question meant that the British economy had become sclerotic. The industrial relations settlement characterised by the Social Contract's tripartite approach, with its 'beer and sandwiches' mind-set, had failed to reconcile the divergent needs and wants of union leaders, ministers, business leaders and most of all the general public. 
Callaghan's Government weathered the IMF financial storm. By spring of 1978 inflation had fallen to $10 \%$ - from the high of $36 \%$ in summer 1975 - and by the autumn over half of the IMF loan had been repaid. The economy was more stable than it had been for a number of years. The decentering consequences however, for many citizens who voted Labour in 1974, in the form of cuts to public expenditure were stark. Callaghan's decision against calling an autumn general election exposed Labour to the infamous winter of 1978 which brought a further wave of industrial action by public sector unions. The effect was serious for people relying on front-line public services and deleterious for Labour. In the public mind they were seen as a government unable to prevent trade unions from taking irresponsible strike action and seemingly associated with one crisis after another.

A further decentering effect of the IMF Crisis was that it solidified, in the minds of a number of social democrats including the Prime Minister, the Chancellor and the Home Secretary, that Keynesian political economy had clear limits. The persistent running of budget deficits led to sharp bouts of inflation, and concomitantly, to increased unemployment. But whilst the IMF Crisis was the portent that Labour's political economy must adapt, it was not the death-knell for Keynesianism as Tomlinson (2004) notes:

Once the IMF seal of approval had been given, and the exchange rate strengthened, Labour started to reflate the economy and to limit inflation by continuing with the social contract. Keynesianism was not dead. (Tomlinson, 2004: 66)

It is more accurate to suggest that the political economy of British social democracy had reached its frontier. The IMF Crisis was a pivotal decentering event and the intellectual and policy consequences of the decision-making of Callaghan's Government affected British politics as a whole, and politicians as a group, be they social democrats, conservatives or liberals. The British state with its Keynesian, welfare capitalist disposition, was faced with 
This is the author's final version of a manuscript accepted for publication as Beech, M. (2020). Brexit and the decentred state. Public Policy and Administration. https://doi.org/10.1177/0952076720905008

intellectual challenges by thinkers on Labour's New Left such as Stuart Holland (1975) and the Conservative’s New Right such as Sir Keith Joseph and Jonathan Sumption (1979).

Middlemas (2001) is correct to argue that:

...the new right critics who steered with the changed tide after 1974 and the deeper, colder current below the surface, were not wrong to focus on the intrinsic gap between the state's aspirations as legislator (in Adam Smith's use of the word) and its effectiveness actually to change individual and collective patterns of behaviour in civil society. (Middlemas, 2001:217)

The first Thatcher government was the beneficiary of Labour's governmental travails and the decentering effects of the 1970s and sought to alter 'patterns of behaviour' by rolling back the state as Rhodes (1997) notes:

Although the British government is expert at inventing rationales for its administrative reforms, none the less the many and varied changes are linked by the consistent aims of pushing back the frontiers of the state and cutting public spending. (Rhodes, 1997:87)

Edward Heath, Harold Wilson, James Callaghan and at the tail-end of the decade, Margaret Thatcher, found themselves confronted by the complexities of the United Kingdom in the 1970s. Whilst government is necessarily challenging, the aggregation of the moral, social, economic ferment of this decade led to political upheaval, sharp divisions and a question mark hanging over the effective governability of the British state and respect for the rule of law within the nation. It is argued here that the idea of the decentered state can help social scientists make sense of the changes that take place in the governance of the British state and, in our time, chief among those is the phenomenon of Brexit. The article asserts that Brexit is 
This is the author's final version of a manuscript accepted for publication as Beech, M. (2020). Brexit and the decentred state. Public Policy and Administration. https://doi.org/10.1177/0952076720905008

a decentering phenomenon in and of itself. Much in the same way as the economic crises of 1970s, the British state is experiencing shock, schism, rupture and is characterised by disputes of an unusually vehement political and social nature within and without political parties. The article moves now to analyse three aspects of Brexit, namely the vote; the negotiation; and the imaginings of a post-EU world, and how each one contributes to the decentering of state governance.

\section{The Vote}

The poll held on $23^{\text {rd }}$ June 2016 is a product of the EU Referendum Act 2015 which received Royal Assent on $17^{\text {th }}$ December 2015. This made good the commitment to hold an 'in-out referendum' on the United Kingdom's membership of the EU in the 2015 Conservative Party General Election manifesto (Conservative Party, 2015). There are, nevertheless, longer-term factors why the Conservative Prime Minister of the day, David Cameron, included the manifesto commitment. The rise of the United Kingdom Independence Party (UKIP); a growing restlessness by Eurosceptic back benchers during the 2010 Parliament; and the liberalism of Cameron as Conservative Party Leader and Prime Minister are long-term contributory factors (Beech, 2017).

Citizens of the United Kingdom voted to leave the EU by a poll which read, 'Should the United Kingdom remain a member of the European Union or leave the European Union?' On a turnout of $72 \%$ (33.55 million) a narrow margin of $52 \%$ to $48 \%$ (17.41 million to 16.14 million) electors opted to Vote Leave (BBC, 2016). They did so for a plurality of reasons. In a poll of 12,369 voters taken on the day of the referendum, Ashcroft (2016) found that of Leave voters the factors informing their decision was as follows: regaining control of laws $49 \%$, regaining control of borders and immigration 33\%, unable to affect future EU memberships and direction 13\% and economic advantage outside of the EU 6\% (Ashcroft, 2016). 
This is the author's final version of a manuscript accepted for publication as Beech, M. (2020). Brexit and the decentred state. Public Policy and Administration. https://doi.org/10.1177/0952076720905008

As the polling data suggests, an important reason for Leave voters was a dissatisfaction with mass immigration from the EU. In particular, the effect of mass low skilled and unskilled migration. This tended to be a targeted complaint against migration from the 2004 Accession 8 countries (A8) $)^{3}$ and the 2007 Accession 2 countries (A2) ${ }^{4}$. Much less focus was given to Cyprus and Malta who also joined the EU in 2004 and Croatia who acceded in 2013. The context of the complaint about mass immigration from the EU by Leave voters can be understood with reference to data from Oxford University's Migration Laboratory. By the first quarter of 20153 million EU nationals were living in the United Kingdom of which 1.9 million were in employment (Migration Observatory, 2016). These figures for 2015 published the year of the referendum help to illustrate the legitimacy of the concern about mass immigration from the EU. The following quotation from the Oxford Migration Laboratory contextualises migration flows since the A8 with data on migration from the EU since 1991:

Inflows of EU nationals migrating to the UK stood at 250,000 in 2016, down from 269,000 in 2015. EU inflows were mainly flat for the 1991-2003 period, averaging close to 61,000 per year. Citizens from new EU member states are included in the data from 2004 onwards, after which the estimated EU migration inflows increased considerably. (Oxford Migration Observatory, 2017 http://www.migrationobservatory.ox.ac.uk/resources/briefings/eu-migration-toandfrom-the-uk/)

If the two most important reasons why a majority of electors voted Leave are to regain parliamentary sovereignty and to control immigration from member states of the EU and, if one seeks to further understand the vote, then it follows that one needs to understand which type of voters voted Leave. Again, using data from the data set captured by Ashcroft (2016) 
on the day of the referendum, one can express the share of Leave voters according to party identification:

\begin{tabular}{|l|l|}
\hline Party Identifier & \% of Leave voters \\
\hline Conservative & 40 \\
\hline UKIP & 25 \\
\hline Labour & 21 \\
\hline Liberal Democrats & 5 \\
\hline SNP & 3 \\
\hline Greens & 2 \\
\hline Other & 2 \\
\hline Plaid Cymru & 1 \\
\hline
\end{tabular}

(Ashcroft, 2016)

The decentering effect of the vote began prior to the referendum. The mere idea of a Bill that sought to legislate for an 'In-Out' referendum on the United Kingdom's continued membership of the EU was a rupture in the UK-EU relationship. The referendum campaign exacerbated this rupture and the decentering effects were felt through the shocks and schisms of partisan argument. This occurred at the level of household, workplace, community, region and nation. For example, with regard to online dialogue, the Centre for the Analysis of Social Media at Demos reported that throughout the campaign and in its aftermath a troubling level of uncivil dialogue and hate speech occurred (Demos, 2016).

The nadir of the referendum campaign was the murder of Jo Cox MP on $16^{\text {th }}$ June in Birstall, West Yorkshire. Cox was murdered by Thomas Mair, a far-right activist who targeted her because she was a progressive politician supportive of the EU, the rights of immigrants and refugees. Cox's murder brought into sharp focus the vulnerability of politicians (Cox was 
murdered on her way to a constituency surgery); it reminded the public of the threat to civil peace from neo-Nazi elements; and it raised the question of the tone of political discourse during the referendum campaign. In an act of rare political unity, and in honour of Jo Cox's memory, the Labour Party's mainstream rivals agreed not to contest the by-election in her Batley and Spen constituency.

\section{The Negotiation}

The second of the three aspects of Brexit, and how it contributes to the decentering of state governance, is the negotiation. After triggering Article 50 of the Lisbon Treaty on $29^{\text {th }}$ March 2017, and with a sense of confidence in her party's poll numbers relative to the Labour Party under Jeremy Corbyn, May called a general election. The reasoning behind this was ostensibly to seek a mandate to deliver Brexit. The shock of the loss of the Conservative Party's modest majority of 13 seats in the House of Commons on $8^{\text {th }}$ June and the subsequent need to enter into a 'confidence and supply' agreement with the Democratic Unionist Party, reinforced the sense of division felt across the country. The result sent a message to the EU that May, as Prime Minister and her Cabinet colleagues, were soon to recommence the Brexit negotiations from a position of weakness. Though May fought a poor campaign and lost her party's majority, 13.6 million electors supported the Conservatives which is the second highest total vote in British electoral history (Apostolova, 2017:6).

The Labour Party performed surprisingly better gaining 30 seats and garnering $40 \%$ of the share of the vote which in the last twenty years was only higher in 1997. Corbyn's position was strengthened much to the dismay of the majority of the Parliamentary Labour Party who continue to oppose his leadership. Corbyn, an erstwhile critic of the European project and acolyte of fellow Eurosceptic Tony Benn, allegedly voted Remain but campaigned gently 
This is the author's final version of a manuscript accepted for publication as Beech, M. (2020). Brexit and the decentred state. Public Policy and Administration. https://doi.org/10.1177/0952076720905008

during the referendum and was rewarded with a wave of Remain voters in the 2017 general election. The most curious Remain seat that swung Labour was Kensington, returning Emma Dent Coad as its Member of Parliament, with a majority of 20.

With the general election over the formal negotiations began. This was three months after Article 50 was triggered. On $19^{\text {th }}$ June 2017 Her Majesty's Government's lead negotiator, the Secretary of State for Exiting the EU, David Davis met with his counterpart Michel Barnier, the European Commission appointed Chief Negotiator for the United Kingdom Exiting the EU. The negotiations between Her Majesty's Government and the EU are time limited. After six months a joint report was published tentatively outlining areas of negotiated agreement at the close of what is termed 'phase 1':

Both Parties have reached agreement in principle across the following three areas under consideration in the first phase of negotiations, on which further detail is set out in this report:

a. protecting the rights of Union citizens in the UK and UK citizens in the Union;

b. the framework for addressing the unique circumstances in Northern Ireland; and c. the financial settlement.

Progress was also made in achieving agreement on aspects of other separation issues. The positions detailed in this report form a single and coherent package. Agreement in principle has been reached on the package as a whole, as opposed to individual elements. Under the caveat that nothing is agreed until everything is agreed, the joint commitments set out below in this joint report shall be reflected in the Withdrawal Agreement in full detail. This does not prejudge any adaptations that might be appropriate in case transitional arrangements were to be agreed in the second phase of the negotiations, and is without prejudice to discussions on the framework of the future relationship. (HM Government, 2017:1) 
This is the author's final version of a manuscript accepted for publication as Beech, M. (2020). Brexit and the decentred state. Public Policy and Administration. https://doi.org/10.1177/0952076720905008

Whilst some progress was made, it is important to note the principle outlined in the report that, 'that nothing is agreed until everything is agreed'. It is because Brexit is an existential crisis for the EU that Barnier and his team sought to convey the sense that they were upholding the integrity of the European project. This is a central part of the strategy of deterring future exits from the EU and playing to the large group of dedicated British Remainers within government and across the state that leaving the EU is not in the best interests of the United Kingdom. As the clock ticked down towards the $29^{\text {th }}$ March 2019 the sense of urgency increased. This pressured both sides. The prospect of losing tariff free access to the United Kingdom is problematic for the EU as financial journalist Simon Lambert (2016) points out:

Some 44 per cent of our exports in goods and services go to the EU, but 53 per cent of our imports of the same come from the bloc. Britain's balance of payments problem might for once be to our advantage here. But break things down to an individual country level and Britain's importance varies. For example, keeping free trade with Britain is much more important to Germany, which sells us lots more goods than we sell to it, than it is to France or Italy - where the deficit is smaller. (Lambert, 2016)

May's personal statecraft has manifested the decentering effect of Brexit on state governance. The Parliamentary Conservative Party - as one of the two great parties of state - remains deeply riven by Brexit. May's Cabinet was intentionally constructed to guarantee a 'pragmatic Remainer' majority. Conservatives of this disposition whilst preferring to continue the United Kingdom's membership of the EU pragmatically accept the result of the referendum and seek to broker the most advantageous deal to secure an economic partnership with the EU. To this end, May's Cabinet met at Chequers and produced the 'Chequer's Plan' which swiftly became the Government White Paper on 'The Future Relationship between the 
This is the author's final version of a manuscript accepted for publication as Beech, M. (2020). Brexit and the decentred state. Public Policy and Administration. https://doi.org/10.1177/0952076720905008

United Kingdom and the EU' (HM Government, 2018) published on 12 July 2018. This document achieved two specific things. Firstly, it moved the Government's agenda on from the Prime Minister's Lancaster House speech of 2017, which explicitly stated that the United Kingdom was leaving the EU:

We are leaving the European Union, but we are not leaving Europe. And that is why we seek a new and equal partnership - between an independent, self-governing, Global Britain and our friends and allies in the EU. Not partial membership of the European Union, associate membership of the European Union, or anything that leaves us half-in, half-out. We do not seek to adopt a model already enjoyed by other countries. We do not seek to hold on to bits of membership as we leave. No, the United Kingdom is leaving the European Union. And my job is to get the right deal for Britain as we do (May, 2017)

Secondly, it exposed the Parliamentary Conservative Party's divergent perspectives. This was seen in the actions and intentions of key members of May's Cabinet, the Secretary of State for Exiting the EU, David Davis, and Foreign Secretary, Boris Johnson, who resigned. Their resignations were in protest of what they interpreted as the Government reneging on the commitment stipulated by May in her Lancaster House speech and in the sentiment expressed during her Conservative Leadership campaign during a speech to supporters in Birmingham when she famously stated that 'Brexit means Brexit' (May, 2016).

These two factors helped to weaken the negotiating posture of the Her Majesty's Government and demonstrate the decentring effects of Brexit.

From summer to autumn 2018 the 'Chequers Plan' evolved into the Draft Agreement (DEXEU, 2018), to give it its abbreviated title, and David Davis' successor at the Department for Exiting the European Union (DExEU), Dominic Raab, appeared to be supportive of 
May's softer Brexit posture. On $14^{\text {th }}$ November the Draft Agreement was published and Raab, followed by fellow Cabinet colleague Esther McVey (Secretary of State for Work and Pensions), resigned citing a lack of confidence that the Draft Agreement delivers a meaningful Brexit and risks disaggregating Northern Ireland from the United Kingdom because of the negotiated 'Irish backstop'. Two days later, Stephen Barclay, Member of Parliament for North East Cambridgeshire and a Leave supporter, replaced Raab at DExEU.

In the four weeks after these resignations the decentering effects of Brexit spilled over from Her Majesty's Government (who on $11^{\text {th }}$ December postponed a vote on the Draft Agreement) to the internal management of the Conservative Party. On $12^{\text {th }}$ December $15 \%$ of the Parliamentary Conservative Party, spearheaded by the European Research Group, submitted letters of no confidence in May's leadership of the Party to Sir Graham Brady, Chairman of the 1922 Committee, thus triggering a confidence vote. Later that evening, after the votes were counted, May had achieved a majority of votes: 200 to 117 . The overwhelming number of her supporters were 'pay-roll' votes - members of the Government. The media reported that May pledged to resign as Party Leader prior to the 2022 general election.

The opening month of the New Year brought the largest defeat of a Government in the modern era of British politics. On $15^{\text {th }}$ January 2019, a mere ten weeks from 'Brexit day', 432 to 202 MPs expressed their deep dissatisfaction in Her Majesty's Government and in its Draft Agreement. This defeat was a marriage of convenience between Brexiteers and ardent Remainers; conservatives and progressives; and included MPs from the Conservative Party, the Democratic Unionist Party, the Labour Party, the Liberal Democrats, the Scottish Nationalist Party, Plaid Cymru, five independent MPs and, the Green Party MP, Caroline Lucas. What could be said with certainty was that the vast majority of the House of Commons was in unity against the Draft Agreement. In the immediate aftermath of the 
This is the author's final version of a manuscript accepted for publication as Beech, M. (2020). Brexit and the decentred state. Public Policy and Administration. https://doi.org/10.1177/0952076720905008

defeat, the Leader of the Opposition, Jeremy Corbyn, tabled a motion of no confidence in the Government. The following day the Democratic Unionist Party fulfilled its 'confidence and supply' agreement with the Conservative minority government to ensure that the motion was defeated by $325-306$.

On $12^{\text {th }}$ March Her Majesty's Government lost the second meaningful vote 242-391 and the third meaningful vote 286-344 on what was supposed to be 'Brexit Day', 29 ${ }^{\text {th }}$ March. After such Parliamentary humiliation, despite pledging to the 1922 Committee (the committee of Conservative backbench MPs) that she would resign if her deal passed, the Prime Minister sought an extension to Article 50 from the European Commission. Preferring either $12^{\text {th }}$ April or $22^{\text {nd }}$ May (the day before the 2019 EU Parliament elections) and then $30^{\text {th }}$ June, the Prime accepted the EU Commission's preference of $31^{\text {st }}$ October. At the time of writing, the Prime Minister is committed to a further meaningful vote in the House of Commons. Her Majesty's Government continues to seek to get the Withdrawal Deal through and is working closely with the Labour Party under Jeremy Corbyn, the one-time Bennite Eurosceptic whose Parliamentary colleagues and activist base is ardently pro-EU, but whose English heartlands outside of the capital voted overwhelmingly for Leave. The effects of Brexit as a decentering phenomenon remain evident for the Conservative Party, the Labour Party, Her Majesty's Government, the House of Commons in particular and the nation in general.

\section{The Imaginings of a Post-EU World}

The third of the three aspects of Brexit, and how it contributes to the decentering of state governance, is what can be referred to as the 'imaginings' of a post-EU world by competing ideational traditions. These are traditions shaped by values. The phenomenon of Brexit has brought into sharp focus the fact that the social fabric of the United Kingdom is riven by the 
values gap ${ }^{5}$. The values gap refers to the conflicting sets of values that characterise British, and especially, English society. These sharply differing sets of values held by citizens who share much in common in terms of their ethnicity, language and culture explain the contrasting outlooks over many issues from Brexit to gay marriage to the Human Rights Act and patriotism. Goodhart (2017) conceives that British politics is being affected by different tribes, some relatively new, and the seemingly tribal character of contemporary Britain is one shaped by differing values. The values gap as understood by the author is the principal factor behind sociocultural division in contemporary British politics and says something about the divide between cosmopolitans and conservatives. This is of particular pertinence for the Labour Party whose Parliamentary Party is overwhelmingly cosmopolitan but much of its inclined-voter base in the North and the Midlands of England is more culturally and socially conservative. Brexit is neither the cause of a disunited kingdom nor is it part of the origin story. In fact, Brexit is a consequence of the growing values gap in British, and especially, in English society.

There are a number of identifiable 'imaginings' of the United Kingdom in a post-EU world. Some are more obvious than others. The author's purpose here is not to speculate about each specific aspect but to draw out ideational narratives that are presently competing in British politics.

The first group comprise the most ardent Remainers. These pro-EU politicians agitated for ‘ever closer Union' and are advocates of a 'People's Vote' or second referendum (Open Britain, 2018). Members of this group are from a number of political parties including $90 \%$ of Labour MPs (Walker, 2018), the Liberal Democrats, the Greens, the SNP, Plaid Cymru, a handful of Conservative MPs and Change UK: The Independent Group. High profile figures from this ideational perspective include, Keir Starmer, Tom Watson, Liz Kendall, Vince 
This is the author's final version of a manuscript accepted for publication as Beech, M. (2020). Brexit and the decentred state. Public Policy and Administration. https://doi.org/10.1177/0952076720905008

Cable, Tim Farron, Caroline Lucas, Nicola Sturgeon, Leanne Wood, Dominic Grieve, Chuka Umunna, Anna Soubry and Heidi Allen. Their ideational tradition is progressive. They view the EU as a repository of progressive values and beliefs and fear that the United Kingdom, outside of the EU, will necessitate a more conservative political culture. This goes some way to explain their desire to defend the free movement of people, the Single Market and the European Court of Justice's approach to human rights. For such politicians the EU is a bulwark of progressivism against conservative forces within and without the Conservative Party. Economically, such political actors insist that the United Kingdom must remain in the European Economic Area (EEA) with its Single Market and Customs Union. For them the least bad option is the 'Norway model'. Membership of the EU is a normative rather than a pragmatic decision. It is a commitment to cosmopolitanism and globalism.

The second group can be understood as pragmatic pro-EU politicians. These Remainers accept the result of the referendum. The politicians in this group comprise a majority of the Parliamentary Conservative Party (Mance and Lindsay, 2017) and a smaller number of Labour MPs. They include Prime Minister Theresa May, Chancellor of the Exchequer Philip Hammond, Amber Rudd, Dan Jarvis and Gareth Snell. The need to reach a negotiated or 'Soft Brexit' is the marker of this group's pragmatism. This group supports the Government's deal. They tend to be liberal in economic and social outlook. They agitate for a customs agreement rather than a 'Canada style' free trade deal.

The third group are Leavers. Eurosceptic MPs who desire that the United Kingdom extricate itself from all EU rationalities. Of this group in the House of Commons the mainstay are Conservatives (especially members of the European Research Group) but include a small number of Labour members. The most thoroughly Eurosceptic parties are UKIP and the 
This is the author's final version of a manuscript accepted for publication as Beech, M. (2020). Brexit and the decentred state. Public Policy and Administration. https://doi.org/10.1177/0952076720905008

Democratic Unionist Party. Well known Eurosceptics in British public life include Jacob Rees-Mogg, Nigel Farage, Boris Johnson, Michael Gove, David Davis, Steve Baker, Frank Field, Kate Hoey, John Mann, Graham Stringer, Arlene Foster and Nigel Dodds.

The issue of Parliamentary sovereignty, control of British borders and money are of central importance for Eurosceptics. There is however no consensus on the type of model the United Kingdom should adopt post-EU membership. Opinion in this group ranges from a 'Canada style' free trade deal to a 'Hard Bexit' where the United Kingdom exits without a deal and operates under World Trade Organisation terms. This group is quite ideationally diverse, containing socially conservative Parliamentarians who have a high view of Britain's past and its propensity to be rich, safe and free outside of the EU. Many are economic liberals but the Labour and DUP Eurosceptics are advocates of a more interventionist political economy.

These competing ideational narratives of the United Kingdom's post-Brexit relationship with the EU are contingent. They depend upon the traditions of thought and the webs of values and beliefs of elite level political actors. They represent attitudes towards the British state and, crucially, towards society. These three groups: ardent Remainers, pragmatic Remainers and Leavers are engaged in a contest of values and ideas broadly explained and understood as the progressive tradition, the liberal tradition and the conservative tradition.

The vote is the foundational decentring event. Of the three aspects outlined above, the effect of the vote has been felt most strongly throughout the UK and the EU. In the post 23rd June 2016 period, the political culture of the UK is mapped and measured by whether one is Leave or Remain. The negotiation, in the period after Article 50 was triggered, has reinforced perceptions of Leavers and Remainers. Her Majesty's Government's pursuit of what some term a 'soft Brexit' pleases few and, at the time of writing, carries no majority in Parliament. 
This is the author's final version of a manuscript accepted for publication as Beech, M. (2020). Brexit and the decentred state. Public Policy and Administration. https://doi.org/10.1177/0952076720905008

The imaginings of a post-EU world serves as a means for scholars to interpret contemporary elite level aspirations for future politics rooted in ideational traditions.

\section{Conclusion}

The British state arguably reached its governing zenith through the crises-stricken governments of Clement Attlee in the immediate post-war years. Yet the degree of economic and social reform undertaken is unparalleled from the NHS and national parks to nationalisation and full employment. For all of the Labour Party's internal impediments such as vehement policy arguments over rearmament, NATO, the nuclear bomb; distributionist debates between Bevanites and Gaitskellites; regular plotting to depose Attlee; the British state's pecuniary vulnerabilities; social democracy was possible. Attlee left the United Kingdom, a social democracy, albeit a fragile, American-dependent one. In his day the United Kingdom was a kingdom founded upon solid rock, hewn from vast reserves of shared values, beliefs and dispositions. Beneath it lay a broad consensus of ethics and patriotism which was formed over many decades but was most crucially fashioned by the collective sacrifice during the Second World War.

By the 1970s fissures had appeared in the foundation stone of the British state and they widened greatly in the four succeeding decades. The decentred state is a useful explanatory tool to explain and understand change in state governance. Brexit is a decentering event, the most potent in the post-war era, but not dissimilar in the effects of rupture, shock, schism and disputes of the 1970s. One that continues to affect the British state but also British society. In the discussions of the vote, the negotiations and the 'imaginings' of a post-EU world one can observe contested beliefs, a 'diversity of governing practices' and policy dilemmas. 
By the $23^{\text {rd }}$ June 2016, it became more appropriate to conceive that the boundaries of British society had been reached. Reached not in the sense of having been fully realised but reached in the sense that it is no longer meaningful to speak of the British society. Today the United Kingdom is more a collection of clefts: English, Scottish, Welsh, Northern Irish; metropolitan and provincial; cosmopolitan and nationalist; progressive and conservative; pro-EU and Eurosceptic. The United Kingdom does not merely disagree about the lie of the land, but about its political map, compass and preferred post-Brexit destination.

\section{Acknowledgements}

I would like to thank participants at the IES Center for British Studies, Decentred State workshop, at UC Berkeley in April 2018 for their feedback on an earlier draft of the paper. I would like to thank Mark Bevir for his helpful comments and Claire Beech with the preparation of the manuscript.

\section{Funding}

The author gratefully acknowledges the IES Center for British Studies at UC Berkeley for providing financial support to participate in the Decentred State workshop.

\section{References}

Apostolova V et al (2017) General Election 2017: Results and Analysis. Briefing Paper no CBP 7979. London: House of Commons Library. 
This is the author's final version of a manuscript accepted for publication as Beech, M. (2020). Brexit and the decentred state. Public Policy and Administration. https://doi.org/10.1177/0952076720905008

Ashcroft M (2016) How the United Kingdom voted on Thursday... and why. Available at: https://lordashcroftpolls.com/2016/06/how-the-united-kingdom-voted-and-why/ (accessed 18 February 2019).

BBC News (2016) EU Referendum Results. Available at:

http://www.bbc.co.uk/news/politics/eu referendum/results (accessed 18 February 2019).

Beech M (2017) Brexit and its Aftershocks. Available at:

https://www.youtube.com/watch?v=hSPp zoHeDQ (accessed 18 February 2019).

Beech M (2011) The Left and Englishness. In Aughey A and Berberich C (eds) These

Englands: A Conversation on National Identity. Manchester: Manchester University Press, 137-154.

Bevir M (2013) A Theory of Governance. Berkeley: University of California Press.

Coates D (1975) Labour in Power? A Study of the Labour Government 1974-1979. London: Longman.

Conservative Party (2015) Strong Leadership A Clear Economic Plan, A Brighter More Secure Future. London: Conservative Party.

Demos (2016) Hate Speech after Brexit. Available at:

https://www.demos.co.uk/project/hatespeech-after-brexit/ (accessed 18 February 2019). 
This is the author's final version of a manuscript accepted for publication as Beech, M. (2020). Brexit and the decentred state. Public Policy and Administration. https://doi.org/10.1177/0952076720905008

Department for Exiting the European Union (2018) The Draft Agreement on the withdrawal of the United Kingdom of Great Britain and Northern Ireland from the European Union and the European Atomic Energy Community. London: DExEU.

Evans G and Menon A (2017) Brexit and British Politics. Cambridge: Polity Press.

Gamble A (2016) What's British about British Politics?. In: Heffernan et al (eds)

Developments in British Politics 10. Basingstoke: Palgrave Macmillan, pp. 1-19.

Goodhart D (2017) The Road to Somewhere: The New Tribes Shaping British Politics.

London: Penguin.

Hicks S (2018) Explaining Postmodernism: Skepticism and Socialism from Rousseau to Foucault. Loves Park, IL: Ockham's Razor Publishing.

Hickson K (2005) The IMF Crisis of 1976 and British Politics. London: I.B. Tauris.

HMG (1969) In Place of Strife: A Policy for Industrial Relations, Cmnd 3888. London: HM Stationery Office.

HMG (1971) Industrial Relations Act. London: HM Stationery Office.

HMG (1974) Trade Union and Labour Relations Act. London: HM Stationery Office. 
This is the author's final version of a manuscript accepted for publication as Beech, M. (2020). Brexit and the decentred state. Public Policy and Administration. https://doi.org/10.1177/0952076720905008

HM Government (2017) Joint report on progress during phase 1 of negotiations under Article 50 TEU on the UK's orderly withdrawal from the EU. London: HM Stationery Office.

HM Government (2018) The Future Relationship Between the United Kingdom and the European Union, Cm 9593. London: HM Stationery Office.

Holland S (1975) The Socialist Challenge. London: Quartet Books.

Joseph K and Sumption J (1979) Equality. London: John Murray Publishers.

Lambert S (2016) How much does the EU need Britain's trade? Brexit means we'll find out.

This is $\quad$ Money, 30 June. Available at:

http://www.thisismoney.co.uk/money/comment/article3666465/How-does-EU-need-Britain-

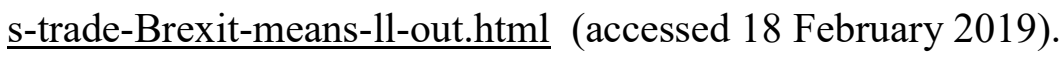

Manwaring R and Beech M (2018) The Case of the British Labour Party: Back to the Wilderness. In Manwaring R and Kennedy P (eds) Why the Left Loses: The Decline of the Centre-Left in Comparative. Bristol: Policy Press, pp. 25-38.

Marsh D and Rhodes R (1992) Policy Communities and Issue Networks: Beyond Typology. In: Marsh D and Rhodes R (eds) Policy Networks in British Government. Oxford: Clarendon Press, pp. 249-268.

Mance H and Lindsay M (2017) Majority of new Conservatives MPs back UK to remain in EU. Financial Times, 23 June. 
This is the author's final version of a manuscript accepted for publication as Beech, M. (2020). Brexit and the decentred state. Public Policy and Administration. https://doi.org/10.1177/0952076720905008

May T (2016) We can make Britain a country that works for everyone. Birmingham, 11 July. Available at: http://press.conservatives.com/post/147947450370/we-can-make-britainacountry-that-works-for (accessed 18 February 2019).

May T (2017) The Government's Negotiating Objectives for Exiting the EU. London, 17 January. Available at: https://www.gov.uk/government/speeches/thegovernmentsnegotiating-objectives-for-exiting-the-eu-pm-speech (accessed 18 February 2019).

Middlemas K (2001) When did Postwar Britain End?. In James S and Preston V (eds) British Politics Since 1945: The Dynamics of Historical Change. Basingstoke: Palgrave, pp. 200218.

Open Britain (2018) https://www.peoples-vote.uk/ (accessed 18 February 2019).

Oxford Migration Observatory (2017) EU Migration to and from the UK. Available at: http://www.migrationobservatory.ox.ac.uk/resources/briefings/eu-migration-to-and-fromtheuk/ (accessed 18 February 2019).

Plantinga A (1990) God and Other Minds. Ithaca: Cornell University Press.

Plantinga A (2000) Warranted Christian Belief. Oxford: Oxford University Press.

Rhodes R and Marsh D (1992) Policy Networks in British Politics: A Critique of Existing Approaches. In: Marsh D and Rhodes R (eds) Policy Networks in British Government. Oxford: Clarendon Press, pp. 1-26. 
This is the author's final version of a manuscript accepted for publication as Beech, M. (2020). Brexit and the decentred state. Public Policy and Administration. https://doi.org/10.1177/0952076720905008

Rhodes R (1997) Understanding Governance: Policy Networks, Governance, Reflexivity and Accountability. Buckingham: Open University.

Scruton R (2016) Fools, Frauds and Firebrands: Thinkers of the New Left. London: Bloomsbury.

Tomlinson J (2004) Economic Policy. In Seldon A and Hickson K (eds) New Labour, Old Labour: The Wilson and Callaghan Governments, 1974-1979. London: Routledge,

Walker P (2018) Tory and Labour MPs at odds with party views over Brexit, poll finds. The Guardian, 22 January.

1 Whilst the author opposes the normative basis of the philosophy of Michel Foucault, post-modernism and Cultural Marxism, the idea of 'decentering' which emanates from his work, is both interesting to social scientists and useful as an explanatory tool. For a reliable account of epistemology see A. Plantinga (1990) God and Other Minds (Ithaca: Cornell University Press) and A. Plantinga (2000) Warranted Christian Belief (Oxford: Oxford University Press). For a clear rebuttal of post-modernism see S.R.C. Hicks (2014) Explaining 
Postmodernism: Skepticism and Socialism from Rousseau to Foucault (Ockham's Razor

Publishing) and for a critique of Foucault see chapter 4 of R. Scruton (2016) Fools, Frauds and Firebrands: Thinkers of the New Left (London: Bloomsbury).

2 For more on what is meant by the English mind(s) see M. Beech (2011) 'The Left and Englishness' in A. Aughey and C. Berberich (eds.) These Englands: A Conversation on National Identity (Manchester: Manchester University Press) p.137-138.

3 Czech Republic, Estonia, Hungary, Latvia, Lithuania, Poland, Slovakia, Slovenia 4 Bulgaria and Romania.

${ }^{5}$ For more on this argument see R. Manwaring and M. Beech (2018) 'The Case of the British Labour Party: Back to the Wilderness in R. Manwaring and P. Kennedy (eds.) Why the Left Loses: The Decline of the Centre-Left in Comparative (Britstol: Policy Press) pp. 25-38. 